\title{
Social Media Learning Activities (SMLA): Implications for Design
}

\author{
Ghania E. Zgheib \\ University of Balamand, Lebanon \\ Nada Dabbagh \\ George Mason University
}

\begin{abstract}
This study explored how experienced faculty are using social media to support student learning. It analyzed the types of social media learning activities (SMLAs), their design, the cognitive processes that they support, and the types of knowledge that students engage in when completing SMLAs. Data gathered from five different cases of six faculty using social media in their courses revealed that social media has the potential to support student learning and promote different levels of cognitive processes and types of knowledge. Results also revealed that experienced faculty select social media tools based on their technology features or their popularity in the field of study, and they recommend integrating several media sources in the design of a single SMLA. Furthermore, this study suggested that experienced faculty who use social media, specifically wikis and blogs, use them as Learning Management Systems (LMS). Finally, the social factor of social media was not evident in the design of the learning activities, and faculty reported promoting more dialogue in their revised SMLA. The findings of this study yielded significant considerations for faculty when designing SMLA.
\end{abstract}

Keywords: social media, social media learning activities, social media design, instructional design, online learning, LMS

Zgheib, G. E., \& Dabbagh, N. (2020). Social media learning activities (SMLA): Implications for design. Online Learning, 24(1), 50-66. https://doi.org/10.24059/olj.v24i1.1967

\section{Social Media Learning Activities (SMLA): Implications for Design}

In the last two decades, the world has experienced a degree of networked digital connectedness that exceeds the limits of traditional communication tools such as phone or email. The rise of social media over the last ten years has led to a wired universe impacting the way people interact with each other and the way they process the wealth of information surrounding them. Social media technologies have become integral in today's learning environments, especially for college students, leading to a paradigm shift in the education system calling for learner collaboration, personalization, and user-generated content. 
Social media, also referred to as Web 2.0 applications or technologies (Ravenscroft, Warburton, Hatzipanago \& Conole, 2012; Valjataga, Pata, Tammets, 2011), are defined as "a group of Internet-based applications that build on the ideological and technological foundations of Web 2.0, and that allow the creation and exchange of user-generated content" (Kaplan \& Heinlein, 2010, p.61). There are hundreds of social media technologies at the user's disposal and many of them share similar affordances like networking, communicating, and sharing while other tools have additional distinguishing features. Kitsantas and Dabbagh (2010) and Dabbagh and Reo (2011b) classified social media technologies as follows:

- Experience- and resource-sharing tools that enable online/social bookmarking, blogging, wiki-ing, and microblogging such as Delicious, WordPress, PbWorks, and Twitter;

- Media sharing tools that enable social tagging such as Flickr and YouTube;

- Social networking tools that enable socio-semantic networking such as Facebook and LinkedIn;

- Communication tools such as email and web-conferencing tools like Skype.

In a recent EDUCAUSE Center for Applied Research (ECAR) study, Brooks and Pomerantz (2017) reported that $97 \%$ of undergraduate students own a smartphone and $78 \%$ of these students consider these devices as moderately important for their academic achievement. The use of mobile devices and mobile apps are driving forces in the increase of adopting social media (Bannon, 2012). Perrin (2015) reported that 90\% of young adults (18-29 year-olds) use social media. Likewise, in a 2015 ECAR study, students requested the use of social media as a learning tool (Dahlstrom, et al., 2015). Research shows that students are mainly using social media technologies for collaboration through online file sharing tools, online sharing of information through websites, tracking and managing their academic schedule, and communicating with peers (Smith, 2017).

On the other hand, faculty adoption of social media to support student engagement and learning has been on the rise. Seaman and Tinti-Kane (2013) reported that $41 \%$ of faculty in higher education use social media in their teaching with a higher percentage in the Humanities and Arts disciplines. They also reported that faculty mostly use wikis and blogs for instructional purposes and prefer using online videos through YouTube and similar platforms as course resources. Similarly, del Valle, Gruzd, Haythornthwaite, Paulin and Gilbert (2017) reported that multimedia repositories, social networking sites, and document sharing tools where the most commonly used tools for teaching. Del Valle et al. (2017) also reported a correlation between faculty personal use of social media and academic use; the more faculty use social media for personal benefit, the more likely they are to integrate these tools in their teaching.

While social media use for teaching and learning is on the rise at the tertiary level, few studies have examined how faculty are designing learning activities using social media and whether faculty are leveraging the intrinsic or integral affordances of social media for teaching. Understanding how experienced faculty are using social media in higher education is essential to developing best practices for implementing social media in teaching and learning contexts. 


\section{Social Media as Learning Resources}

A review of existing research suggests a positive impact of social media on student learning, specifically on students' engagement with peers and with the content, and as tools to supplement classroom teaching (Yang \& Chang, 2012; Churchill, 2009; Rambe, 2012; Hung \& Yuen, 2010; Domizi, 2013; Fox \& Varadarajan, 2011; Menkhoff \& Bengtsson, 2012; Lichter, 2012). These studies revealed that faculty from different disciplines including education, pharmacy, language learning, public administration, information technology, science, business, music, and visual arts are using social media to support their face-to-face or online courses.

Studies revealed that social media learning activities mainly engaged the students in connecting with peers and with learning outside the classroom, commenting on each other's work, collaborating, and creating projects through microblogging platforms, social networking sites, media sharing tools, and experience and resource sharing tools. A review of the literature conducted by Zachos, Paraskevopoulou-Kollia and Anagnostopoulos (2018) synthesized the benefits of using online social networks (OSNs) like Facebook and Twitter in education. Their findings suggested that OSNs support student formal and informal learning, provide opportunities for students to be exposed to new perspectives for learning through virtual communities, enhance student communication, collaboration, and motivation.

Furthermore, blogs have been used for writing essays, giving students opportunities to comment on each other's blogs, access course material, post course artefacts, form online groups and as a reflection journal (Chawinga, 2017; Churchill, 2009; Farwell \& Kruger-Ross, 2013; Gedera, 2011; Yang \& Chang, 2012). Wikis have been used as collaboration tools to complete group projects and Capstone projects, for peer reviewing and editing, for sharing resources, asking questions, and reflecting on readings (Abdekhodaee, Chase \& Ross, 2017; Berthude \& Gliddon, 2018; Bonne \& Lin, 2013; Franklin \& Thankachan, 2013; Hu \& Johnston, 2012; Oskoz \& Elola, 2011; Park et al., 2010). Social networking tools are used for asking and answering questions and participation in discussion forums, sharing resources, inviting guest speakers, and posting notifications and reminders (Cain \& Policastri, 2011; Hung \&Yuen, 2010; Irwin, Ball, Desbrow \& Leveritt, 2012; Junco, 2012; Omar, Embi, \&Yunus, 2012; Rambe, 2012). Microblogging tools such as Twitter are being used to post tweets about a course topic, tweet class announcements and reminders, discuss a topics in class and outside class, ask and answer questions, and vote on answers (Andrade, Castro \& Ferreira, 2012; Chawinga, 2017; Domizi, 2013; Fox \& Varadarajan, 2011; Gao, Luo, \& Zhang, 2012; Junco, Heibergert \& Loken, 2011; Lin, Hoffman, \& Borengasser, 2013). Media sharing tools such as YouTube and Flickr are being used to create a video and share it, upload and tag photos, comment on photos and videos, summarize important lecture notes and record demonstrations (Bussert, Brown, \& Armstrong, 2008; Lehmen, Dufren \& Lehman, 2010; Lichter, 2012; Orùs, 2016; Price, Tsui, Hart \& Saucedo, 2011). While the research is clear regarding the benefits of social media use for learning, it is lacking in the area of designing social media learning activities (SMLA). In other words, how are faculty integrating SMLA in their teaching? Is there a well-defined process that guides the design of SMLA?

\section{Social Media Learning Design Frameworks}

Existing Web 2.0/social media learning design frameworks have taken into consideration the interaction between technology and pedagogy. Bower, Hedberg, and Kuswara (2010) proposed a Web 2.0 learning design process through the following steps: (a) identifying learning goals; (b) identifying the type of knowledge that students should gain from the activity; (c) identifying the 
cognitive processes that the students should engage in; (d) selecting the type of pedagogy, and finally; (e) selecting the "preferred modalities of representation" such as audio, video, and text. Two main components of Bower et al.'s (2010) Web 2.0 learning design process are cognitive processes established by Bloom's Taxonomy of Cognitive Domains and knowledge dimensions or types of knowledge, factual, conceptual, procedural, and metacognitive, proposed by Anderson and Krathwohl (2001). Bower et al. presented a conceptual framework that cross-tabulated Bloom's revised cognitive processes with the types of knowledge and another component, types of online pedagogies.

Similarly, Karvounidis, Chimos, Bersimis, and Douligeris (2015) presented i-SERF as a guiding framework for the integration of social media in higher education. I-SERF is a two-layered framework in which the first layer is educational and draws on the interaction between three forms of knowledge: content, technology, and pedagogy while the second layer proposes an evaluation methodology to the first layer. This framework adds the elements of the learner's self-regulation and self-evaluation that were missing in previous frameworks (Karvounidis, Chimos, Bersimis, and Douligeris (2018).

Since Bloom's taxonomy plays a key role in the design of learning activities, Bosman and Zagenzysk (2011) and Lightle (2011) interpreted social media learning using Bloom's Taxonomy. For instance, they reported that social bookmarking promotes remembering, social blogging promotes understanding, social file sharing supports applying, social collaboration supports analyzing, social decision-making tools stimulate evaluating, and social creativity sharing tools promote creating. However, Bosman and Zagenzysk's (2011) and Lightle's (2011) analysis of social media in the light of Bloom's taxonomy is only perceptual. Hence, there is a need to formalize our understanding of social media use for learning and the levels of cognitive skills and types of knowledge though evidence-based research.

\section{Current Study and Research Questions}

This study aimed to explore how experienced faculty are using social media to support learning activities in their courses. More specifically, it aimed to analyze social media learning activities (SMLA) in light of cognitive processes and types of knowledge that students engage in when completing these activities. Research questions addressed in this study were:
a. What types of learning activities are designed through social media?
b. What cognitive processes do SMLA promote?
c. What types of knowledge do SMLA promote?
d. What strategies do experienced faculty use to design SMLA?

\section{Method}

This study was conducted in a public higher education institution in the mid-Atlantic region of the U.S. A qualitative approach was used with quantification of some results. A multiple case-study design was implemented and data was gathered from five cases of six faculty $(n=6)$ who were using social media in their courses for at least two years. Students enrolled in the six courses taught by the faculty participants were considered secondary participants, and consented to observation of their course-related posts in the examined SMLA. Out of 279 students who were enrolled in the six courses, $115(n=115)$ students gave consent to the researcher to observe their course-related social media posts. 
Table 1

Description of Participants

\begin{tabular}{|c|c|c|c|c|c|c|c|}
\hline $\begin{array}{c}\text { Faculty } \\
\text { Participants }\end{array}$ & $\begin{array}{l}\text { Course Title in } \\
\text { Which SM is } \\
\text { Used }\end{array}$ & $\begin{array}{l}\text { Number of } \\
\text { Semesters } \\
\text { Teaching } \\
\text { this Course }\end{array}$ & $\begin{array}{l}\text { Course } \\
\text { Delivery } \\
\text { Format }\end{array}$ & $\begin{array}{l}\text { Years in } \\
\text { Higher } \\
\text { Ed }\end{array}$ & $\begin{array}{l}\text { Year } \\
\text { Started } \\
\text { Using SM }\end{array}$ & $\begin{array}{l}\text { Number of } \\
\text { Students } \\
\text { per Course }\end{array}$ & $\begin{array}{l}\text { Number of } \\
\text { Student } \\
\text { Consent }\end{array}$ \\
\hline Faculty A & $\begin{array}{l}\text { Digital Future: } \\
\text { Digital Activism } \\
\text { (DFDA) }\end{array}$ & 2 & $\begin{array}{l}\text { Hybrid } \\
6 \text { credits }\end{array}$ & 17 & 1997 & 18 & N/A \\
\hline Faculty B1 & \multirow{2}{*}{$\begin{array}{l}\text { Food, Culture, } \\
\text { and Technology } \\
\text { (FTC) }\end{array}$} & 3 & \multirow{2}{*}{$\begin{array}{l}\text { Face-to-Face } \\
\text { Non-credit }\end{array}$} & 15 & 2007 & \multirow[t]{2}{*}{6} & \multirow[t]{2}{*}{5} \\
\hline Faculty B2 & & 3 & & 18 & 2010 & & \\
\hline \multirow{3}{*}{ Faculty C } & $\begin{array}{l}\text { Leading Change } \\
\text { (LC) }\end{array}$ & 3 & $\begin{array}{l}\text { Face-to-Face } \\
4 \text { credits }\end{array}$ & \multirow[t]{3}{*}{19} & \multirow[t]{3}{*}{2009} & \multirow[t]{2}{*}{25} & \multirow[t]{2}{*}{22} \\
\hline & Leadership & & & & & & \\
\hline & $\begin{array}{l}\text { Theory and } \\
\text { Practice (LTP) }\end{array}$ & 3 & $\begin{array}{l}\text { Face-to-Face } \\
3 \text { credits }\end{array}$ & & & 20 & 16 \\
\hline Faculty D & $\begin{array}{l}\text { Introduction to } \\
\text { Digital Studies } \\
\text { (IDS) }\end{array}$ & 1 & $\begin{array}{l}\text { Face-to-Face } \\
3 \text { credits }\end{array}$ & 9 & 2005 & 25 & 22 \\
\hline Faculty E & $\begin{array}{l}\text { Introduction to } \\
\text { Business } \\
\text { Information } \\
\text { Systems (IBIS) }\end{array}$ & 5 & $\begin{array}{l}\text { Face-to-Face } \\
3 \text { credits }\end{array}$ & 3 & 2011 & 185 & 50 \\
\hline
\end{tabular}

\section{Data Sources}

Data sources included syllabi and course documents describing the social media learning activities (SMLAs), students' posts in SMLAs, and faculty initial and follow-up interviews. The syllabi and the descriptions of the SMLA provided baseline data about the requirements and deadlines that guided the analyzes of the SMLAs. Faculty participants were interviewed at the beginning and end of the semester in initial and follow-up interviews giving participants the freedom to express their range of perceptions about the use of social media in their courses (Maxwell, 2013). Both interviews were semi-structured and included open-ended questions. In the initial interview, faculty were asked to analyze their SMLAs in light of Bloom's taxonomy, and they were asked about their perceptions regarding social media to support student learning, the criteria they use to choose their social media, and strategies they used to develop the learning activities involving social media. In the follow-up interview, faculty were asked to describe their experiences with the outcomes of the social media activity, whether it has achieved what it was intended to achieve, the types of knowledge that students gained, and revisions they would make to their SMLAs. Social media platforms used by the faculty and the students were also observed online and then students' posts and interactions in the SMLA were analyzed. The focus of the observations was to identify cognitive processes and knowledge domains observed in students' SMLA posts. 


\section{Data Analysis}

Influenced by Bower et al.'s conceptual framework for Web 2.0 learning design, two taxonomies guided the analysis of the SMLAs in this study: original and digital versions of Bloom's Taxonomy of Cognitive Domain (Churches, 2009) (see Figure 1), and Knowledge Dimensions or Types of Knowledge (Anderson \& Krathwohl, 2001).

Krathwohl (2002) provided a detailed explanation of the different types of knowledge:

- Factual Knowledge-The basic elements that students must know to be acquainted with a discipline or solve problems in it.

- Conceptual Knowledge-The interrelationships among the basic elements within a larger structure that enable them to function together.

- Procedural Knowledge-How to do something; methods of inquiry, and criteria for using skills, algorithms, techniques, and methods.

- Metacognitive Knowledge-Knowledge of cognition in general as well as awareness and knowledge of one's own cognition (p. 215).

As presented in Tables 3 and 4, both the researcher " $R$ " and the faculty participants " $F$ " analyzed the social media activities as described in the syllabi. Content analysis of SMLAs was conducted using preestablished categories pulled from Bloom's Taxonomy of Cognitive Domains and Krathwohl's (2000) Knowledge Dimensions. The students' posts in social media were also analyzed by the researcher using the preestablished categories. Percentages in Tables 3 and 4 suggest the extent to which cognitive processes and knowledge dimensions where evident in the students' posts. The boxes that include " $F$ " indicate that Faculty identified the presence of the corresponding cognitive process or knowledge domain in the SMLA and the " $R$ " shows the researcher's analysis of the SMLAs. Patterns relevant to the absence of cognitive processes and knowledge domains were identified based on triangulated data from faculty analysis, researcher's analysis, and students' posts. In some boxes, the researcher's analysis and the analysis of students' posts highly converged as indicated by a percentage greater than 50 .

In order to achieve fairness in the analysis of students' posts in SMLAs, 30\% of the posts in each SMLA were selected, resulting in a total of 343 student posts analyzed. The $30 \%$ of posts were sampled from students' beginning, middle, and end of activity, in order to analyze the students' work across the whole activity. The researchers conducted the same analysis to achieve inter-rater reliability.

Initial and follow-up interviews were analyzed using deductive coding (Miles \& Huberman, 1994). Deductively, categories from the initial and follow-up interview questions were first established based on the research questions that were addressed in the interviews. Further, open coding was conducted to analyze data that does not align with the preestablished categories. Credibility was established by obtaining member checks, triangulation of data, and long-term involvement in data collection. Since this multiple-case study is holistic in nature, a meta-matrix was created in order to focus on the findings across cases rather than on every individual case (Miles \& Huberman, 1994). 


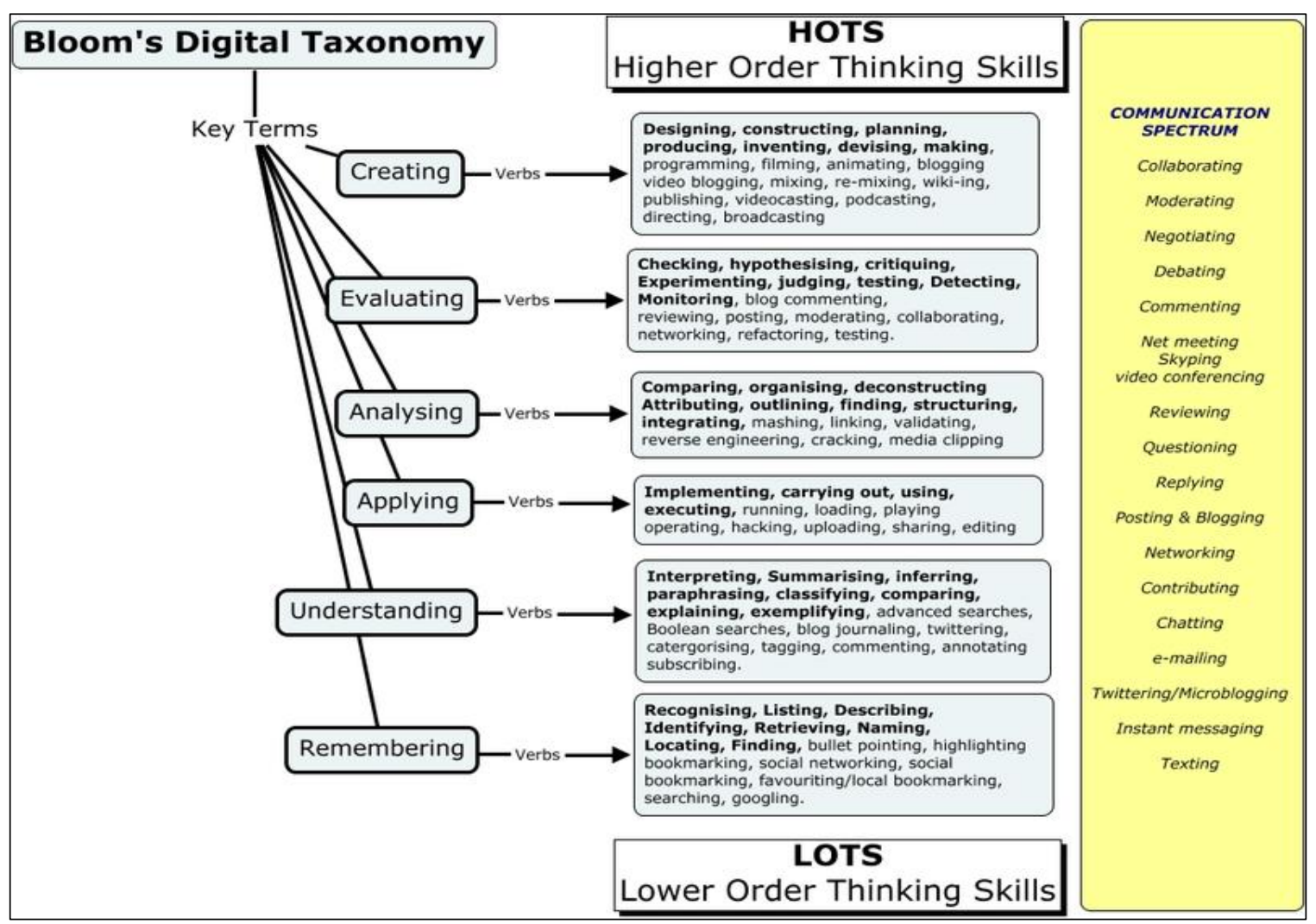

Figure 1. Bloom's digital taxonomy (adapted from Churches [2009]).

\section{Research Findings}

The analysis revealed that overall, social media has the potential to support student learning and promote different levels of cognitive processes and types of knowledge. The findings are reported by research questions below.

\section{Research Question 1: What types of learning activities are designed through social media?}

A total of 12 SMLA across the five courses were identified in this study. Out of these activities, there were four microblogging activities, two blogging activities, three wiki activities, one podcasting activity, one infographic activity integrated into a blog, and one YouTube activity (see Table 2). Out of the 12 SMLA, 2 were unstructured used for informal class reminders, announcements and discussions while 10 were structured, graded, and described in the syllabi. The latter represented $5 \%$ to $100 \%$ of the total course grade. Seven out of the structured 10 activities were mandatory and the remaining three were optional. In the optional activities, students had the alternative to select SMLA or traditional non-social media activities identified in the course syllabus that would count toward the course grade. 
Table 2

Social Media Learning Activities (SMLAs) Included in the Study

\begin{tabular}{|c|c|c|c|c|c|}
\hline $\begin{array}{l}\text { Social Media } \\
\text { and Course } \\
\text { Title } \\
\end{array}$ & $\begin{array}{l}\text { Social Media Learning } \\
\text { Activities (SMLAs) }\end{array}$ & $\begin{array}{l}\text { Private } \\
\text { vs. Public }\end{array}$ & $\begin{array}{l}\text { Structured vs. } \\
\text { Unstructured }\end{array}$ & $\begin{array}{l}\text { Mandatory } \\
\text { vs. Optional }\end{array}$ & $\begin{array}{l}\text { Course } \\
\text { Grade } \\
\text { Percentage } \\
\end{array}$ \\
\hline $\begin{array}{l}\text { Microblogs } \\
\text { Leading } \\
\text { Change (LC) }\end{array}$ & $\begin{array}{l}\text { Personal Transformation } \\
\text { Experiment using } \\
\text { Twitter. }\end{array}$ & Public & Structured & Mandatory & $15 \%$ \\
\hline $\begin{array}{l}\text { Introduction to } \\
\text { Business } \\
\text { Information } \\
\text { Systems } \\
\text { (IBIS) }\end{array}$ & $\begin{array}{l}\text { Online Class } \\
\text { Participation at Twitter }\end{array}$ & Public & Structured & Optional & $5 \%$ \\
\hline $\begin{array}{l}\text { Digital } \\
\text { Futures: } \\
\text { Digital } \\
\text { Activism } \\
\text { (DFDA) }\end{array}$ & $\begin{array}{l}\text { Digital Activism Twitter } \\
\text { Projects }\end{array}$ & Public & Structured & Mandatory & $15 \%$ \\
\hline DFDA & $\begin{array}{l}\text { Twitter in-class and small } \\
\text { group participation }\end{array}$ & Public & Unstructured & Optional & Unspecified \\
\hline $\begin{array}{l}\text { Blogs } \\
\text { Food, Culture } \\
\text { and } \\
\text { Technology } \\
\text { (FCT) }\end{array}$ & Language Blog & Public & Structured & Mandatory & $100 \%$ \\
\hline $\begin{array}{l}\text { Introduction to } \\
\text { Digital Studies } \\
\text { (IDS) }\end{array}$ & $\begin{array}{l}\text { Digital Studies Course } \\
\text { Blog }\end{array}$ & Public & Structured & Mandatory & $20 \%$ \\
\hline $\begin{array}{l}\text { Wiki } \\
\text { Leadership }\end{array}$ & $\begin{array}{l}\text { Collaborative Note- } \\
\text { Taking }\end{array}$ & Private & Structured & Mandatory & $25 \%$ \\
\hline $\begin{array}{l}\text { Theory and } \\
\text { Practice } \\
\text { (LTP) }\end{array}$ & Wiki as LMS & Private & Unstructur-ed & Optional & Unspecified \\
\hline $\begin{array}{l}\text { Podcasts } \\
\text { FCT }\end{array}$ & Podcasting & Public & Structured & Mandatory & Unspecified \\
\hline $\begin{array}{l}\text { Infographic } \\
\text { FCT }\end{array}$ & Creating Infographics & Public & Structured & Mandatory & Unspecified \\
\hline $\begin{array}{l}\text { YouTube } \\
\text { DFDA }\end{array}$ & $\begin{array}{l}\text { Participatory Action } \\
\text { Video using YouTube }\end{array}$ & Private & Structured & Mandatory & $50 \%$ \\
\hline $\begin{array}{l}\text { Wikipedia } \\
\text { DFDA }\end{array}$ & Wikipedia & Public & Structured & Optional & $25 \%$ \\
\hline
\end{tabular}


The use of the social media technologies to support the SMLAs was either private or open to the public, allowing any person to observe the students' work or interact with them. Nine out of 12 SMLAs were public and three were private. Microblogging or Twitter activities were all public because the tool does not have private features. Two blogging activities were public. Both were also searchable online, although only specified users could contribute to them. Wiki activities were private and access to them requires an invitation from the wiki administrator. However, Wikipedia activity was public because students had to edit an existing Wikipedia entry and could get feedback on their edits from the public. Podcasts and infographics activities were public since they were posted on a public blog while the YouTube activity was also private, since students posted their videos privately to YouTube and only students and faculty had access to them.

\section{Research Question 2: What cognitive processes do SMLAs promote?}

As explained in the data analysis, the SMLAs were analyzed using Bloom's original and digital taxonomy of cognitive processes to identify the level of cognitive processes that students are expected to achieve while completing the learning activities, as well as evidence of students' cognitive processes in their SMLA posts. The analysis of the data across courses and social media technologies revealed two overarching themes. First, both higher and lower levels of cognitive processes were evidenced through SMLAs. Second, alignment was perceived between particular social media affordances and cognitive processes.

These overarching themes were based on common patterns observed in the analysis. Based on Bloom's Digital Taxonomy, "Remembering" and "Understanding" were perceived as basic cognitive processes promoted in all the examined SMLAs (see Table 3). The analysis of blogging and wiki activities revealed that blogs and wiki SMLAs may promote several cognitive processes ranging from "Remembering" to "Creating." Furthermore, the analysis suggested that higher levels of cognitive processes may be promoted mainly by blogs, wikis, and media sharing tools such as the Collaborative Note Taking activity, the Language Blog, and the Digital Studies Course Blog. Finally, the results suggested that SMLAs may promote "Analyzing" through hyperlinking and may promote "Evaluating" through judging and critiquing peer work.

Table 3

Sample Analysis of SMLAs Based on Bloom's Taxonomy

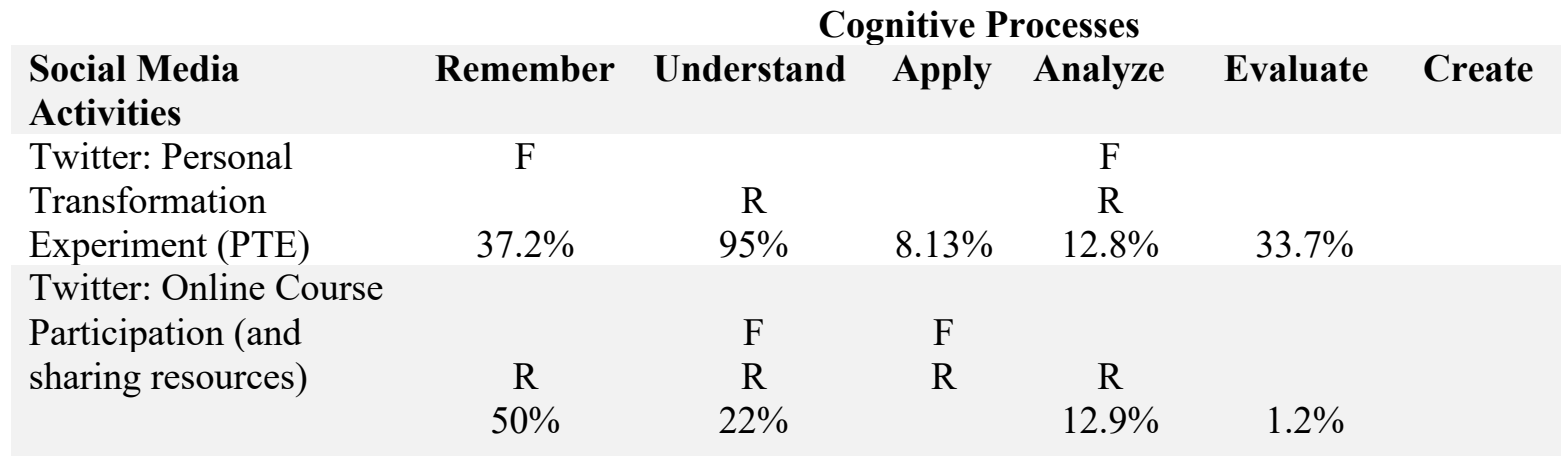

Note. Letter "F" indicates the faculty member's content analysis of the SMLA as presented in the syllabus. Letter "R" shows the researcher's content analysis of the SMLA as described in the syllabus. The \% shows the researcher's analysis of the presence of cognitive processes in the students' posts on social media. 


\section{Research Question 3: What types of knowledge do SMLAs promote?}

Both faculty and the researcher analyzed the knowledge domains perceived in SMLAs as listed in the course syllabi and documents. The students' posts in SMLAs were also analyzed in terms of types of knowledge using pre-established categories (see Table 4). The convergence in the data analysis revealed two overarching themes: all types of knowledge were evidenced through SMLA and there is a perceived alignment between particular social media affordances and types of knowledge.

The overarching themes were based on common patterns observed in the data analysis. The analysis of students' posts in seven SMLAs revealed that students achieved factual knowledge about the course content in five out of the seven observed SMLAs, which suggests that factual knowledge is a common outcome in SMLAs. Results also suggested that linking and tagging in SMLAs promoted conceptual knowledge especially in activities that required them to use \#hashtags or include links to external resources. Procedural knowledge was mainly evident in activities that required students to create a product such as a Personal Language Blog, podcasts, or infographics. In both activities, students engaged in a procedure to create the final product and to learned how to use it. Finally, metacognitive knowledge was identified in three out of seven activities that were examined. Students were expected to think about their learning or how they might use the subject matter to reflect on their own cognition. The design of the SMLAs in these courses suggested that students had several chances to reflect on their learning and revise their posts before sharing them.

Table 4

Sample Analysis of the SMLAs Based on Krathwohl's (2002) Knowledge Dimensions

\section{Knowledge Domain}

$\begin{aligned} & \text { Social Media Activities } \\ & \text { Twitter: Personal }\end{aligned}$
$\begin{aligned} & \text { Transformation Experiment } \\ & \text { (PTE) }\end{aligned}$
R

\section{Research Question 4: What strategies do experienced faculty use to design SMLA?}

Experienced faculty with social media were selected for this study in order to capture best practices in designing SMLAs. In the initial interview, faculty were asked about the criteria they 
used to select social media technologies, and how they paired it with the learning activity. The follow-up interview captured faculty's reflection on the SMLA and suggestions for future revisions. The two overarching themes that emerged in data collected for this research question were Faculty Reliance on Social Media Affordances and Fit With their Course Content and Integrating Additional Media Sources to Enhance SMLAs. These themes were the result of six common patterns observed across findings related to strategies that faculty use when designing SMLAs:
a. Matching the discipline with the social media;
b. Selecting social media based on affordances;
c. Taking advantage of the affordances of social media;
d. Including media sharing (website, video, audio) in the SMLA;
e. Integrating tools or social media affordances that support dialogue, and;
f. Making the SMLA mandatory and not optional.

\section{Discussion}

\section{Evidence of Several Cognitive Processes and Types of Knowledge in SMLAs}

The analyzed SMLA in this study suggested that all social media tools could promote more than one type of knowledge or level of cognitive processes depending on the design of the SMLA and how students use the social media technology, a finding that is in line with Bower et al. (2010), Bosman and Zagenczyk (2011), Lightle (2011), and Gülbahar, Rapp, Killis and Sitnikova (2017). Findings suggested that wiki SMLAs can promote all levels of cognitive processes, and can support Factual, Conceptual, and Metacognitive knowledge. Blog SMLA can also foster all levels of cognitive processes and can support all types of knowledge, a finding that resonates with Gülbahar et al. (2017). Microblog SMLA can promote Remembering, Understanding, and Analyzing, and foster Factual, Conceptual, and Metacognitive Knowledge. Podcast SMLA can support Creating, Applying, and Remembering, and promote all types of knowledge. Finally, media editing and sharing SMLA can support Creating, Understanding, and Remembering, and promote Factual, Conceptual, and Metacognitive Knowledge.

\section{The Absence of Dialogue}

One of social media's roles is to promote social presence through social networking in addition to shareable user-generated content (Anderson, 2017). As social media is grounded in social learning theory of Bandura, it is supposed to enhance students' self-efficacy beliefs through social interaction in a low-risk environment (Deaton, 2015). The examined SMLAs in this study did not require conversational or interaction tasks among students. This was evidenced in the description of the SMLAs and in the deactivation of the comment feature in the blogging activities, the lack of comments in wikis, and sparse commenting or retweeting between students on Twitter. As a result, the communication took place mainly between faculty-students and not between students-students or students-others. This suggested that the design of the SMLAs were mainly used at the level of "private information management," and "basic interaction or sharing," without taking advantage of the social networking affordance of social media (Dabbagh \& Reo, 2011a). 


\section{Social Media as Learning Management Systems}

Analysis and observations of SMLAs revealed that four out of the five cases in this study used mostly wikis and blogs as social media technologies in their courses, a finding that concurs with Moran, Seaman, and Tinti-Kane (2012), who suggested that wikis and blogs are faculty's most adopted social media tools for teaching. Furthermore, the findings revealed that social media is used to replace Learning Management Systems (LMS) and share course content or communicate with students. More specifically, in courses where blogs and wikis were used, the faculty did not use the institution's LMS to share content and communicate with students. Rather, wikis and blogs were used as an integrative platform to share content with students, post assignment descriptions, and allow students to share their work. In other studies, Meishar-Tal, Kurtz, and Pieterse (2013), Zachos et al. (2018), and Salavuo (2008) reported the advantages of using social media as LMS in promoting collaboration and active learning over traditional institutional LMSs.

This study went a step further and suggested that the public nature of blogs gives them an advantage over LMSs, which are limited to the course participants. For instance, public blogging activities made students' work visible beyond their peers and teacher reaching out to a public audience which made their posts of higher quality and activated their metacognitive knowledge. In line with this finding, Chawinga (2017) reported the benefits of blogs as tools that allow students to write longer posts and comments as there is no word limit which results in self-expression and self-reflection (Deng \& Yueng, 2011). Previous studies revealed blogs' usage as LMSs in some cases, and a platform for students to access course materials and to comment on each other's blogs, and in other cases, they are used as reflective journals or personal writing sites (Churchill, 2009; Farwell \& Kruger-Ross, 2013; Gedera, 2011; Yang \& Chang, 2012).

Wikis are primarily used as collaboration tools and support peer reviewing and editing (Abdekhodaee, Chase \& Ross, 2017; Bonne \& Lin, 2013; Franklin \& Thankachan, 2011; Menkhoff \& Bengtsson, 2012; Ozkoz \& Elola, 2011; Park et al., 2010). The wikis examined in this study resembled LMS in their private access, but little evidence of student social interaction was perceived. Hence, this study revealed that blogs and wikis were used for sharing course content and assignments rather than promoting social interaction and collaboration among students.

\section{Strategies for Designing SMLAs}

This study did not reveal a formal approach or strategy for designing SMLAs. Rather, experienced faculty approached this task differently based on their familiarity with social media technology, the popularity of the tool in their discipline, and affordances of the technology. However, in the follow-up interviews, faculty suggested that SMLAs should be mandatory because students should learn to experiment with technology. This finding resonated with Lin, Hoffman and Borengasse (2013), who explained that Twitter activities should be structured and mandatory so that students participate in them.

Bower et al. (2010) explained that the design of the learning activity and the selection of social media are interdependent. When the faculty in this study designed the SMLAs, some were more intuitive in how they selected the social media technology because they had been using it for a while, while others designed the activity and selected the social media whose technology affordances supported the learning goals of the learning activity. On the other hand, others selected the social media technologies because they were popular and they could experiment with them and add an innovative layer to their course delivery. Therefore, experienced faculty strategies for 
designing SMLAs concurs with Bower et al. (2010), who emphasized the interdependence between social media tool and the design of learning activities. Integrating different media sources within a SMLA was also another design feature that faculty recommended to help students gather information from different sources, a finding confirmed by Soares (2008).

The findings also revealed that while faculty were not aware of Bloom's Taxonomy or did not design SMLA with cognitive processes and types of knowledge in mind, the researcher's analysis showed that SMLAs promoted different cognitive processes and different types of knowledge. This finding suggests that faculty have little pedagogical training. In a previous study, Keengwe, Kidd, and Kyei-Blankson (2009) and Hughes and Zulkifli (2012) explained that faculty need organizational support and technology training in order to use technology in their teaching.

\section{Twitter as a Popular Course Tool}

Although Moran et al. (2012) revealed that faculty use Twitter the least in their courses, Twitter was used by three faculty participants in three out of five cases in this study. Twitter assignments in this study were mainly a micro-reflection activity and course participation tweets about course topics. A more informal activity was in-class participation using Twitter. The findings in this study concurred with previous studies that revealed Twitter as a reflection tool and a platform to post tweets about course related topics (Domizi, 2013; Fox \& Varadarajan, 2011; Junco, Heibergert \& Lokert, 2011; Lin, Hoffman, \& Borengasser, 2013). However, there was little evidence of communication using Twitter in the observed SMLAs, a finding that contradicted previous research that claimed Twitter is a tool that supports communication with the professor and classmates (Fox \& Varadarajan, 2011; Junco, et al., 2011).

\section{Conclusion}

This study and previous studies implied that social media technologies may engage students with the subject matter when integrated in course learning activities. Hence, designing SMLAs that take into account the technology affordances of social media can engage students' higher levels of cognitive processes and knowledge.

Findings from this study inferred that faculty use of social media in their courses is varied. SMLAs can promote learning as perceived by faculty participants in this study. The study also suggested that wikis and blogs may replace and be used as LMS as perceived by faculty in this study. Furthermore, well-structured SMLA activities should take into consideration the social affordances of the tools to optimize the use of these activities and designing SMLAs is a process of reciprocity between the selection of social media affordances and the fit of the tools. Mandatory use of SMLAs in courses may ensure student engagement. The study also suggested that there is a perceived disconnect between faculty intended and observed cognitive processes and types of knowledge of SMLAs. As a result, faculty should receive pedagogical training and support to design more effective SMLAs.

Although the study examined the use of social media in higher education within cases and across cases, because of the nonexperimental design of the study, the impact of social media activities on students' learning was not measured. Furthermore, the study was limited to faculty perceptions and students' posts in social media. Hence, students' perceptions about these SMLA were not explored. Due to the complexity of cognitive processes, identification of students' processes was limited in cases where students had short posts on social media. Furthermore, this study included faculty from a single institution, which might have limited the external validity and the generalizability of the study. Further research could involve the students in the evaluation of these SMLA and their impact on their learning. 


\section{References}

Abdekhodaee, A., Chase, A.-M., \& Ross, B. (2017). Wikis for group work: Encouraging transparency, benchmarking, and feedback. Australasian Journal of Educational Technology, 33(5), 15-31. doi.org/10.14742/ajet.2829

Anderson, T. (2017). How communities of inquiry drive teaching and learning in the digital age. Retrieved from https://teachonline.ca/tools-trends/insights-online-learning/2018-02-27/howcommunities-inquiry-drive-teaching-and-learning-digital-age

Anderson, L., \& Krathwohl, D. (2001). A taxonomy for learning, teaching and assessing: A revision of Bloom's taxonomy of educational objectives. Longman.

Andrade, A., Castro, C., \& Ferreira, S. A. (2012). Cognitive communication 2.0 in higher education: To tweet or not to tweet? Electronic Journal of E-learning, 10 (3), 293-305.

Bannon, D. (2012, December 4). State of the media: The social media report 2012. The Nielson Company. http://www.nielsen.com/us/en/reports/2012/state-of-the-media-the-social-mediareport-2012.html

Berthoud, L., \& Gliddon, J. (2018). Using wikis to investigate communication, collaboration and engagement in Capstone engineering design projects. European Journal of Engineering Education, 43(2), 247-263. doi.org/10.1080/03043797.2017.1332574

Bosman, L., \& Zagenczyk, T. (2011). Revitalize your teaching: Creative approaches to applying social media in the classroom. Social media and Platforms in Learning Environment, 3-15. doi:10.1007/978-3-642-20392-3_1

Bower, M., Hedberg, J. G., \& Kuswara, A. (2010). A framework for Web 2.0 learning design. Educational Media International, 47(3), 177-198. doi:10.1080/09523987.2010.518811

Brooks, D. C., \& Pomerantz, J. (2017). ECAR study of undergraduate students and information technology, 2017. Research report. ECAR. Retrieved from https://library.educause.edu/ /media/files/library/2017/10/studentitstudy2017.pdf

Bussert, K., Brown, N. E., \& Armstrong, A. H. (2008). IL 2.0 at the American University in Cairo. Internet Reference Services Quarterly, 13(1), 1-13. doi:0.1300/J136v13n01_01

Cain, J., \& Policastri, A. (2011). Using Facebook as an informal learning environment. American journal of pharmaceutical education, 75(10), 207. Retrieved from http://www.ncbi.nlm.nih.gov/pmc/articles/PMC3279026/

Chawinga, W. D. (2017). Taking social media to a university classroom: teaching and learning using Twitter and blogs. International Journal of Educational Technology in Higher Education, 14(3). doi:10.1186/s41239-017-0041-6

Churches, A. (2009). Bloom's digital taxonomy. Retrieved from https://www.researchgate.net/publication/228381038_Bloom's_Digital_Taxonomy

Churchill, D. (2009). Educational applications of Web 2.0: Using blogs to support teaching and learning. British Journal of Educational Technology, 40(1), 179-183. doi:10.1111/j.14678535.2008.00865.x

Dabbagh, N., \& Reo, R. (2011a). Impact of Web 2.0 on higher education. In D.W. Surry, T. Stefurak, and R. Gray (Eds.), Technology integration in higher education: Social and organizational aspects (pp. 174-187). IGI Global. 
Dabbagh, N., \& Reo, R. (2011b). Back to the future: Tracing the roots and learning affordances of social software. In M.J.W. Lee and C. McLoughlin (Eds.), Web 2.0-based e-Learning: Applying social informatics for tertiary teaching (pp. 1-20). IGI Global.

Dahlstrom, E., Brooks, D. C., Grajek, S., \& Reeves, J. (2015). ECAR study of students and information technology. Educause. Retrieved from https://library.educause.edu/resources/2015/8/ /media/24ddc1aa35a5490389baf28b6ddb3693.as $\underline{\mathrm{hx}}$

Deaton, S. (2015). Social learning theory in the age of social media: implications for educational practitioners. Journal of Educational Technology, 12(1), 1-6.

Del Valle, M. E., Gruzd, A. Haythornthwaite, C. Paulin, D., \& Gilbert, S. (2017). Social media in educational practice: faculty present and future use of social media in teaching. Proceedings of the 50th Hawaii International Conference on System Sciences. Retrieved from https://www.researchgate.net/profile/Marc Esteve_Del_Valle/publication/317121792_Social_M edia in Educational Practice Faculty Present and Future Use of Social Media in Teachin g/links/59fc3bad0f7e9b9968bb8fc9/Social-Media-in-Educational-Practice-Faculty-Present-andFuture-Use-of-Social-Media-in-Teaching.pdf

Domizi, D. P. (2013). Microblogging to foster connections and community in a weekly Graduate seminar course. TechTrends, 57(1), 43-51. doi:10.1007/s11528-012-0630-0

Donne, V., \& Lin, F. (2012). Special education teacher induction: The Wiki way. The Clearing House, 86, 43-47. doi:10.1080/00098655.2012.735279

Deng, L., \& Yuen, A. H. (2011). Towards a framework for educational affordances of blogs. Computers \& Education, 56(2), 441-451.

Farwell, T. M., \& Kruger-Ross, M. (2013). Is there (still) a place for blogging in the classroom? Using blogging to assess writing, facilitate engagement, and evaluate student attitudes. In K.K.J. Seo (Ed.), Using social media effectively in the classroom: blogs, wikis, Twitter, and more (pp. 207-222). Routledge.

Fox, B., \& Varadarajan, R. (2011). Technology in pharmacy education: Use of Twitter to encourage interaction in a multi-campus pharmacy management course. American Journal of Pharmaceutical Education, 75(5), 1-9. doi:10.5688/ajpe75588

Gedera, D. S. P. (2011). Integration of weblogs in developing language skills of ESL learners. International Journal of Technology in Teaching and Learning, 7(2), 124-135.

Gülbahar, Y., Rapp, C., Kilis, S., \& Sitnikova, A. (2017). Enriching higher education with social media: development and evaluation of a social media toolkit. International Review of Research in Open and Distributed Learning, 18(1), 23-39.

Hu, Q., \& Johnston, E. (2012). Using a wiki-based course design to create a student-centered learning environment: strategies and lessons. Journal of Public Affairs Education, 18(3), 493512 .

Hung, H.-T., \& Yuen, S. C.-Y. (2010). Educational use of social networking technology in higher education. Teaching in Higher Education, 15(6), 703-714. doi:10.1080/13562517.2010.507307

Irwin, C., Ball, L., Desbrow, B., \& Leveritt, M. (2012). Students' perceptions of using Facebook as an interactive learning resource at university. Australasian Journal of Educational Technology, 28(7), 1221-1232. 
Junco, R., Heiberger, G., \& Loken, E. (2011). The effect of Twitter on college student engagement and grades. Journal of Computer Assisted Learning, 27(2), 119-132. doi:10.1111/j.13652729.2010.00387.x

Junco, R. (2012). Too much face and not enough books: The relationship between multiple indices of Facebook use and academic performance. Computers in Human Behavior, 28(1), 187-198. doi:10.1016/j.chb.2011.08.026

Kaplan A. M. \& Haenlein M., (2010). Users of the world, unite! The challenges and opportunities of social media. Business Horizons, 53(1). doi:10.1016/j.bushor.2009.09.003

Karvounidis, T., Chimos, K., Bersimis, S., \& Douligeris, C. (2015). I-SERF: An integrated selfevaluated and regulated framework for deploying web 2.0 Technologies in Higher Education. The Electronic Journal of e-Learning, 13(5), 319-333.

Karvounidis, T., Chimos, K., Bersimis, S., \& Douligeris, C. (2018). Factors, issues and interdependencies in the incorporation of a web 2.0 based learning environment in higher education. Education and Information Technologies, 23(2), 935-955. doi:10.1007/s10639-0179644-8

Kitsantas, A., \& Dabbagh, N. (2010). Learning to learn with Integrative Learning Technologies (ILT): A practical guide for academic success. Information Age Publishing.

Krathwohl, D. R. (2002). A revision of Bloom's taxonomy: An overview. Theory into Practice, 41(4), 212-218.

Lehman, C. M., DuFrene, D. D., \& Lehman, M. W. (2010). YouTube video project: A “Cool” way to learn communication ethics. Business Communication Quarterly, 73(4), 444-449. doi:10.1177/1080569910385382

Lichter, J. (2012). Using YouTube as a platform for teaching and learning solubility rules. Journal of Chemical Education, 89, 1133-1137. doi:10.1021/ed200531

Lin, M. F. G.,Hoffman, E. S., \& Borengasser, C. (2013). Is social media too social for class? A case study of Twitter use. TechTrends, 57(2), 39-45. doi:10.1007/s11528-013-0644-2

Maxwell, J. A. (2013). Qualitative research design an interactive approach. SAGE Publications.

Meishar-Tal, H., Kurtz, G., \& Pieterse, E. (2013). Facebook groups as LMS: A case study. The International Review of Research in Open and Distance Learning, 13(4), 33-48.

Menkhoff, T., \& Bengtsson, M. L. (2011). Engaging students in higher education through mobile learning: lessons learnt in a Chinese entrepreneurship course. Educational Research for Policy and Practice, 11(3), 225-242. doi:10.1007/s10671-011-9123-8

Miles, M. B., \& Huberman, A. M. (1994). Qualitative data analysis: An expanded sourcebook. (2nd ed.). Sage.

Omar, H., Embi, M. A., \& Yunus, M. M. (2012). ESL learners' interaction in an online discussion via Facebook. Asian Social Science, 8(11), 67-74. doi:10.5539/ass.v8n11p67

Orús, C., Barles, M. J., Belanche, D., Casalò, L., Fraj, E., \& Gurrea, R. (2016). The effects of learner-generated videos for YouTube on learning outcomes and satisfaction. Computers and Education, 95, 254-269. doi:10.1016/j.compedu.2016.01.007 
Oskoz, A. \& Elola, I. (2011). Meeting at the Wiki: The new arena for collaborative writing in foreign language courses. In M. J. W. Lee and C. McLoughlin (Eds.), Web 2.0-based e-Learning: Applying social informatics for tertiary teaching (pp. 209-227). IGI Global.

Park, C. L., Crocker, C. Nussey, J., Springate, J., \& Hutchings, D. (2010). Evaluation of a teaching tool-wiki-in online graduate education. Journal of Information Systems Education, 21(3), 313-321.

Perrin, A. (2015). Social Networking Usage: 2005-2015. Pew Research Center. Retrieved from http://www.pewinternet.org/2015/10/08/2015/Social-Networking-Usage-2005-2015/

Pomerantz, J., \& Brooks, C. (2017). ECAR study of faculty and information technology. Educause. Retrieved from https://library.educause.edu/ /media/files/library/2017/10/facultyitstudy2017.pdf

Price, E., Tsui, S., Hart, A., \& Saucedo, L. (2011). Don't erase that whiteboard! Archiving student work on a photo-sharing website. The Physics Teacher, 49(7), 426. doi:10.1119/1.3639151

Rambe, P. (2012). Constructive disruptions for effective collaborative learning: Navigating the affordances of social media for meaningful engagement. Electronic Journal of e-Learning, 10(1), 132-146.

Ravenscroft, A., Warburton, S., Hatzipanagos, S., \& Conole, G. (2012). Designing and evaluating social media for learning: shaping social networking into social learning? Journal of Computer Assisted Learning, 28(3), 177-182. doi:10.1111/j.1365-2729.2012.00484.x

Seaman, J. \& Tinti-Kane, H. (2013). Social media for teaching and learning. Pearson. Retrieved from http://www.pearsonlearningsolutions.com/assets/downloads/reports/social-media-forteaching-and-learning-2013-report.pdf\#view=FitH,0

Smith, E. E. (2017). Social media in undergraduate learning: Categories and characteristics. International Journal of Educational Technology in Higher Education, 14(12). doi:10.1186/s41239-017-0049-y

Soares, D. A. (2008). Understanding class blogs as a tool for language development. Language Teaching Research, 12(4), 517-533.

Valjataga, T., Pata, K., \& Tammets, K. (2011). Considering students' perspectives on personal and distributed learning environments in course design. In M. J. W. Lee and C. McLoughlin (Eds.), Web 2.0-based e-Learning: Applying social informatics for tertiary teaching (pp. 85-108). IGI Global.

Yang, C., \& Chang, Y.S. (2012). Assessing the effects of interactive blogging on student attitudes towards peer interaction, learning motivation, and academic achievements. Journal of Computer Assisted Learning, 28, 126-135. doi:10.1111/j.1365-2729.2011

Zachos, G., Paraskevopoulou-Kollia, E.-A., \& Anagnostopoulos, I. (2018). Social media use in higher education: A review. Education Sciences, 8(4), 194. doi:10.3390/educsci8040194 